\title{
Islamic psycho-immunological approaches in increasing immunity during the COVID-19 pandemic
}

\author{
Imam Maulana ${ }^{1}$, Raisha Fathima ${ }^{1}$, Haiyun $\mathrm{Nisa}^{2}$, and Rina Suryani Oktari ${ }^{1,3^{*}}$ \\ ${ }^{1}$ Faculty of Medicine, Universitas Syiah Kuala, 23111 Jl. Tgk. Syech Abdul Rauf, Darussalam, Banda Aceh, Indonesia \\ ${ }^{2}$ Department of Psychology, Faculty of Medicine, Universitas Syiah Kuala, 23111 Jl. Tgk. Syech Abdul Rauf, Darussalam, Banda \\ Aceh, Indonesia \\ ${ }^{3}$ Tsunami \& Disaster Mitigation Research Centre (TDMRC), Department of Family Medicine, Faculty of Medicine, \\ Universitas Syiah Kuala, Banda Aceh, Indonesia
}

\begin{abstract}
The COVID-19 pandemic has a significant impact on mental health because it can increase the risk of panic, anxiety, and fear in society. New normal conditions with various limitations require people to be adaptive in order to cope with stressors that arise during the pandemic. This condition could interfere with mental health and adversely affect the body's immunity. Stress, through the nervous system, functions to help individuals move actively. In individuals who experience stress, the sympathetic system will activate various organs of the body causing the increment of blood sugar, blood pressure, muscle activities and metabolism which can reduce the immunity of individuals. Besides that, various efforts have been made as a form of controlling the spread of infection such as the application of health protocols, the concept of Iman (Faith), Imun (Immune), Aman (Secure), and vaccination. In addition, there are other efforts done by the Islamic religious people that hold approaches in the form of beliefs and daily life rituals, namely the concept of Dua, Ikhtiar, Tawakkul, and Tawadhu in facing the COVID19 pandemic disaster. This concept is related to the psychoneuroimmunology aspect which, if applied correctly, can have an impact in finding mental resilience.
\end{abstract}

\section{Introduction}

According to the United Nations, individuals in the United States of America (45\%), Iran (60\%) and Republic of China (35\%) got distress during COVID-19. The Lancet Commission on global mental health and sustainable development reported that people are situated on a continuum from mild, time-limited distress to severe mental health conditions in COVID-19 pandemic. Many people are now less able to cope than before because of the stressors generated by the pandemic. Society tends to be in increasing anxiety and distress especially those who had less experience of these. Some get worsening conditions if once affected previously and even develop a mental health condition [1].

In response to the increasing number of COVID-19 cases in Indonesia, The National Task Force informs a program called iman, aman, imun, as the addition to "3M" program that stands for "menggunakan masker" (wearing mask), "mencuci tangan" (washing hands), and "menjaga jarak" (social-distancing). Iman means faith, aman means safety and imun means people encouragement to maintain their immunity [2]. This concept is reflecting the values of faith in conjunction with spirituality as one of the main factors to pursue comprehensive protection against COVID-19.

As the pandemic continues and significantly affects the economy and social life, it's a challenge to prepare society, not only in terms of disease prevention, but also mental attentiveness. Mentally prepared state means a normal life to run along with the period of crisis caused of COVID-19. As distress is the ultimate risk of every individual during the pandemic, immunity is on the edge of its impact. Human body responds to stressors by activating the hypothalamus-pituitary-adrenal axis (HPA axis) that elevates cortisol level, suppressing the immune system. The vicious cycle of stressors and immune suppression carries harms towards psychoneuroimmunology.

The needed approaches are supposed to connect the spiritual aspect to the physical aspect, as implemented in Islamic point of view. all which are dua, ikhtiar, Tawakkul, tawadhu. Dua, such as a prayer to be avoided by disasters; Ikhtiar, such as complying with health protocols correctly, sorting information, and

\footnotetext{
* Corresponding author: okta@unsyiah.ac.id
} 
maintaining a lifestyle, as well as vaccinations; Tawakkul, such as accepting the situation and surrendering to God after doing the best we could; and Tawadhu, which is humbling so that we always stay alert of our conditions. This concept is in line with the mechanism of psychoneuroimmunology which explains the reciprocal effect of mind-body on immunity.[3] Islamic religious rituals have become a part of life, including depicting disasters as a test instead of a punishment that can definitely be faced so that we are out of despair.

The purpose of this study is to examine the approaches of the Islamic concept (Dua, Ikhtiar, Tawakkul, Tawadhu) in facing the COVID-19 pandemic regarding psychoneuroimmunology. This study is expected to be an insight for the society so they can be educated better through life rituals, related to surrounding characteristics and cultures to be easier accepted.

\section{Method}

This study used a systematic literature review with a descriptive method using search engines from databases such as Scopus, Science Direct, DOAJ, Google Scholar, PubMed, SpringerLink, and Sage. The following research questions directed the search strategy, including: i) What is the psychoneuroimmunology concept in Islam? ii) How does it influence immunity? and iii) How does the Islamic psychoneuroimmunology approach increase mental health resilience during the COVID-19 pandemic. To enable for a broader spectrum of literature to emerge from the searches, the databases were searched using the following key terms: "Islam", "mental health", "spirituality", "psychology", "immunology", "COVID-19", "psychoneuroimmunology" and "HPA axis" by adding Boolean Operator "AND" and "OR". As an inclusion criterion, this review only considered articles published in English and Indonesian, then discussing the Islamic concept of psychoneuroimmunology. Articles that do not have full access were excluded from this review. The literature search was conducted from April 10 to August 10, 2021. The total minimum of 30 articles that met the inclusion and exclusion criteria, were included for further analysis.

\section{Result and discussion}

\subsection{Stress and COVID-19 pandemic}

During COVID-19 pandemic, people are constrained to adapt to regulations of social distancing, physical distancing, work from home, and school from home. However, this condition raises new problems, namely limitations in daily activities or living in quarantine. Recent evidence suggests that people who are kept in isolation and quarantine experience significant levels of anxiety, anger, confusion, and stress [4]. Research has also shown that frequent media exposure may cause distress.[5] A systematic review and meta-analysis conducted by Salari et al. 2020 conclude that COVID19 not only causes physical health concerns but also results in a number of psychological disorders (Figure 1) [6].

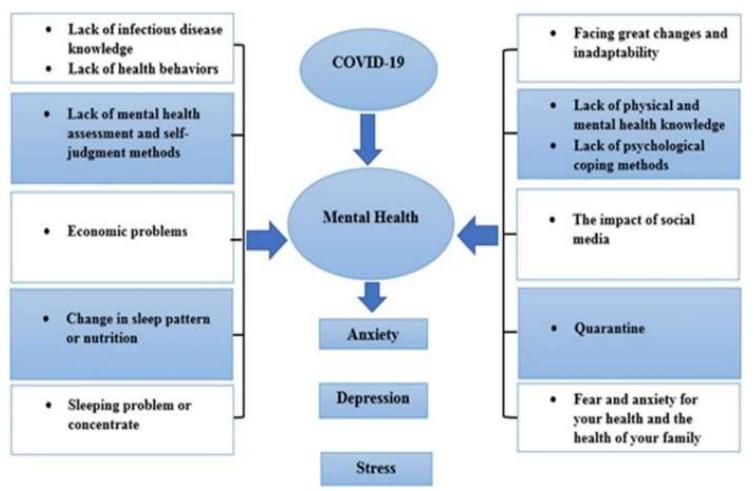

Fig 1. Impacts of COVID-19 pandemic on mental health [6].

Stress defined by Selye (1956) as the effects of anything that fatally threatens homeostasis [7]. Dhabhar-McEwen said that stressor (source of stress) will be responded by the brain (stress perception) then responded by other systems (stress response) [8]. Since COVID-19 has been stated as a pandemic, it unveiled some stressors due to unclarity and changes for all of sudden in certain vital sectors like health, economy and social life. Although the concept of "new normal" has been socialized, the demands to adapt to these conditions have become a challenge.

Physiologically, stress is divided into 3 stages known as the General Adaptation Syndrome (GAS): 1) Alarm Reaction Stages, refers to the initial symptoms of the body under acute stress and the "fight or flight" response. After the initial shock of the stressful event, the body begins to repair itself by lowering cortisol levels and normalizing the physiologic responses (i.e., blood pressure and heart rate). During this recovery phase, the body remains on alert until the stressful event is no longer an issue. However, if the stressful event persists for extended periods of time, the body will adapt to cope with the higher level of stress. The body will continue to secrete stress hormones which keep the body's physical response to stress elevated. This induces the second stage; 2 ) Resistance stage includes symptoms of poor concentration, irritability, and frustration. If the stressful event continues to persist, the body will enter the third stage; 3) Exhaustion Stage, symptoms of this stage include burnout, fatigue, depression, anxiety, and reduced stress tolerance. As the stressful event persists, the body's immune system will continue to weaken. This is due to the suppressive effects of stress hormones on cells of the immune system [9].

Although it seems that stress has only negative effects on the body, it actually also has advantageous effects. Stress which gives disadvantage on the body known as distress, and the one which has an advantageous effect known as eustress. Eustress energizes and motivates us to make a change. It gives us a positive outlook and makes us capable of overcoming 
obstacles and sickness [10]. Distress or eustress depends on how the individual perceives the stress. If they feel that their coping skills are inadequate, they will experience distress. On the other hand, if an individual perceives their coping skills as adequate, they will experience eustress. Transactional Approach outlines that an individual's experience of stress is dependent on their appraisal of their ability to cope with the stressor (Figure 2) [11].

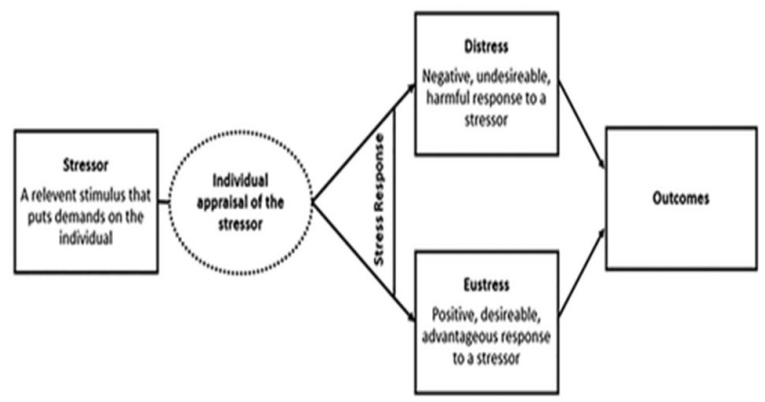

Fig. 1. A visual description of the partial-consensus definition of the stress process [11].

Distresses increase the risk of anxiety, anger, disappointment, frustration, financial problems, and stigma [4]. The most common stressors during the pandemic are fear and anxiety about the self-health and people surrounding [12]. The human body responds to stressors by activating molecular and cellular changes in the brain mediated by activation of the hypothalamuspituitary-adrenal axis (HPA axis) which can elevate cortisol level. Cortisol suppresses the immune system [13].

Psychological stress and distress have been associated with higher levels of oxidative damage [14]. The mechanism remains unclear, and is likely mediated in part by stress-related hormones (e.g., cortisol) as well as health behaviors [15]. The first evidence that low-tomoderate doses of stress may have beneficial effects ("eustress") emerged over a century ago as an "inverted U" relationship between arousal and performance (Figure 3) [16].

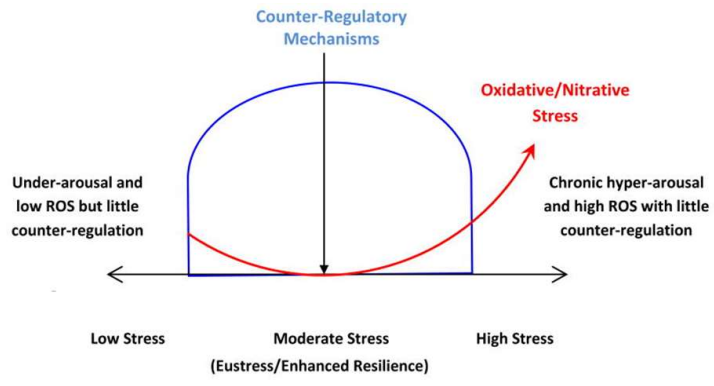

Fig. 3. Moderate Stress can enhance resilience [17].

Research by Aschbacher et al. shows that moderate level of stress perceived were associated with reduced levels of oxidative damage compared to low and high which supports the emerging model that chronic stress exposure promotes oxidative damage through frequent and sustained activation of the HPA axis [17].

This proves that even COVID-19 is a real ordeal, but the wise reaction, Dua, Ikhtiar, Tawakkul and Tawadhu, towards the emerging stress, can maintain the level of stress under its high level.

\subsection{The concept of Dua, Ikhtiar, Tawakkul and Tawadhu towards psychoneuroimmunology}

In Islam, the stress management concept towards stressor is comprehensive. In disaster for example, there are three different point of views: 1) Disaster as musibah, which means something that befalls human beings in the form of something either pleasant or unpleasant. It is usually caused by human sins, including being ignorance of fact; 2) Disaster as bala, which means test (human promotion). Bala is God's will without human involvement. Bala aims to raise the human standing, forgive his sins and purify his soul. it's used in "...And We tried them with good (favors) and bad (disasters) in order to return (to the truth)." Surah al-A'raf [7]: Verse 168; 3) Disaster as azab, which means punishment (punishment of God). In the Qur'an, $a z a b$ is interpreted as torture or an excruciating punishment inflicted by God only on those who are ungodly and do not believe. The religious leaders interpret the disaster that befell the people of the previous prophets such as the people of Prophet Shuaib, the people of Noah, the people of Prophet Lut, the People of Prophet Saleh and the tribe 'Ad people of Prophet Hud as a punishment for not believing [18].

The comprehensive concepts of stress management in Islam consist of Dua, Ikhtiar, Tawakkul, and Tawadhu. The concept is inseparable from the lives of Muslims can be a supporting modality in dealing with existing distress. Dua, Ikhtiar, Tawakkul and Tawadhu were the cultivated values in the perspective of Islam, including the people of Aceh, depicted from the daily religious life rituals. These spiritual activities give tranquility upon the individuals psychologically.

Dua is defined as an expression of the birth of conscience or feeling of need to ask for help or help from Allah (SWT). Dua is essentially an expression of submission of faith to God and of one's neediness. Two types of Dua: 1) Du'ā al-mas'alah (دُعَاءُ الْمَنْأَلَّة du' 'ā'u 'lmas 'alah), or the 'dua of asking.' This type of dua is when one asks for the fulfillment of a need, or that some harm be removed from him/her. For instances, Wakulja alhaqqu wazaqal batil, Innal batilaka nazahuka, meaning: "And say, the truth has come and the falsehood has disappeared, and indeed the falsehood will be destroyed." (Qs: Al-Isra' [17]: 81) which used by Acehnese as part of ritual Tulak Bala (translate: Rejections of disaster); 2) Du'ā al-'ibadah (ذُعَاءُ الْعِبَادةة $d u$ 'a' $u$ ' $l$ - 'ibādah), or the 'dua of worship.' This type of dua includes every single act of worship. Examples would include when a Muslim prays or gives zakāt or fasts. Pajevic et al (2017) in his research towards 100 war veterans divided into two groups (practicing and not practicing daily praying) shows that practice groups 
have a reduction towards risk, impulsiveness, and aggression than their peers who did not practice religion [19].

Besides supplicating through $d u a$, Islam's view in guaranteeing someone's attainment is not separated from God's instruction to humans to make certain efforts, or so called ikhtiar. Ikhtiar means to endeavor to receive better results [20]. It is stated in Quran that emphasized the importance of ikhtiar, as follows, "God does not change the condition of a people unless they change what is in themselves", stated in surah 13 (ArRa'd), verse 11 . This indicates that no matter how truly someone does dua, it must be accompanied by effort. During COVID-19, ikhtiar might mean complying with some rules such as wearing a mask, washing hands and keeping a distance for each individual to hamper the transmission of the virus.

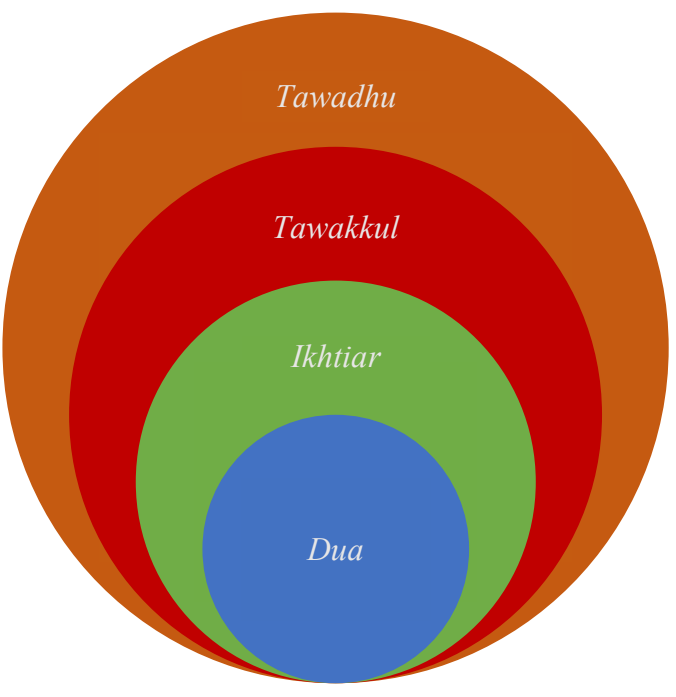

Fig. 3. The configuration of Dua, Ikhtiar, Tawakkul and Tawadhu.

After $d u a$ and ikhtiar, Islam also concerned about human's mind serenity by surrendering to Allah (SWT) following all prayers and efforts done. This is named tawakkul. Tawakkul is an Arabic word emphasizing the reliance on God or "trusting in God's plan" [21]. Being tawakkul also leads someone to do the efforts as best as they could and feel no regrets because they know Allah (SWT) is the best helper and no burdens He gives upon a soul more than it can bear, as stated in Quran, "God does not burden any soul with more than it can bear", surah 2 (Al-Baqara), verse 286. Peace upon someone's feeling after accomplishing hard work is a result after Tawakkul, as strengthen in Quran that said, "And whoever puts all his trust in Allah, He will be enough for him", surah 65 (At-Talaq), verse 3.

Islam concept in shaping someone wise in managing stress is also directing humans to be humble and keep sustaining good deeds, or named tawadhu. Tawadhu or humility indicates humans to stay alert of the recent conditions and do not be too satisfied as if no more efforts are needed. The Messenger of Allah (Peace Be Upon Him) has said, "Allah has commanded me as follows: Show such humility that none of you boasts to others and none of you oppresses another" cited by Muslim, Jannah, 64 [22]. That statement is highlighting the importance of having sincere intentions wholeheartedly to sustainably follow the COVID-19 health protocols amid the pandemic, even in healthy condition or negative from COVID-19 test.

\subsection{Psychoneuroimmunology in Islamic concept}

Conceptualizing Islamic values as the approach in psychoneuroimmunology, in the form of religiousderived mindfulness practices, is considered as mind/body medicine. The mind/body medicine emphasizes the mental state of humans that is able to connect to the psychology and the physical aspect.[23] The mental state is maintained through meditationbased spiritual activities [24].

Several studies found out the improved neuralplasticity and the increased cerebral blood flow (CBF) in the transcendental meditation [25], the increment of abrineurin or brain-derived neurotrophic factor (BDNF) and the decrement of cortisol production in persistent Buddhist meditation [12], and the upgraded brain connectivity in long-term meditators [26]. Interestingly, brain imaging researchers have discerned brain anatomy changes in long-term meditators, like the increased brain cortical thickness in the areas processing sensory and attention $[27,28]$, and the improved grey matter density in the cerebellum, the temporo-parietal junction, the posterior cingulate cortex [29], and also the brain stem [30]. In addition, short term meditation, like a few hours of integrated mind-body training, is advantageous in enhancing white matter integrity of the superior and anterior corona radiata and corpus callosum [31]. It is also claimed that religious-derived mindfulness practices affect positively upon the psychological and physical sector and even become a part of stress-related disorders treatment [32-35].

There are two types of Islamic approach in mind/body medicine, which are Al-tibb al-jismani (physical medicine) and Al-Tibb al-Ruhani (psychological/spiritual medicine). Both approaches are related conjointly since in Islam point of view, human is having two main aspects, spirit (ruh) and body (jism). While it is different from modern medicine that focuses only on the physical aspect [36]. This explanation creates the balance between body and mind to reach overall peace and health of humankind. The implementation of this concept as shown in Table 1. 
Table 1. The instances of Dua, Ikhtiar, Tawakkul and Tawadhu implementation along COVID-19.

\begin{tabular}{|c|c|c|c|}
\hline & $\begin{array}{l}\text { Pre COVID- } \\
19\end{array}$ & $\begin{array}{l}\text { During } \\
\text { COVID-19 }\end{array}$ & $\begin{array}{l}\text { Post } \\
\text { COVID-19 }\end{array}$ \\
\hline Dua & $\begin{array}{l}\text { Asking for } \\
\text { being } \\
\text { avoided from } \\
\text { illness }\end{array}$ & $\begin{array}{l}\text { Asking for } \\
\text { the sickness } \\
\text { to be lifted }\end{array}$ & $\begin{array}{l}\text { Ask for the } \\
\text { healthiness }\end{array}$ \\
\hline Ikhtiar & $\begin{array}{l}\text { Following } \\
\text { Health } \\
\text { Protocols } \\
\text { Getting } \\
\text { vaccinated } \\
\text { Filtering } \\
\text { information } \\
\text { and hoax }\end{array}$ & $\begin{array}{l}\text { Getting } \\
\text { COVID-19 } \\
\text { test } \\
\text { Report to } \\
\text { healthcare } \\
\text { facilities } \\
\text { Following } \\
\text { the doctors } \\
\text { order }\end{array}$ & $\begin{array}{l}\text { Following } \\
\text { Health } \\
\text { Protocols } \\
\text { Filtering } \\
\text { information } \\
\text { and hoax }\end{array}$ \\
\hline Tawakkul & $\begin{array}{l}\text { Not being } \\
\text { panicked } \\
\text { Believe it } \\
\text { could a bala, } \\
\text { instead of } \\
a z a b\end{array}$ & $\begin{array}{l}\text { Believe that } \\
\text { the sickness } \\
\text { is a test } \\
\text { from God }\end{array}$ & $\begin{array}{l}\text { Being } \\
\text { grateful for } \\
\text { being } \\
\text { healthy } \\
\text { again }\end{array}$ \\
\hline \multirow[t]{2}{*}{ Tawadhu } & $\begin{array}{l}\text { Stay alert of } \\
\text { the recent } \\
\text { conditions } \\
\text { not be too } \\
\text { satisfied as if } \\
\text { no more } \\
\text { efforts are } \\
\text { needed }\end{array}$ & \multirow[t]{2}{*}{$\begin{array}{l}\text { Not blaming } \\
\text { anyone } \\
\text { (including } \\
\text { ourselves) } \\
\text { for our } \\
\text { sickness }\end{array}$} & $\begin{array}{l}\text { Stay alert of } \\
\text { the recent } \\
\text { conditions } \\
\text { Keep } \\
\text { following } \\
\text { health } \\
\text { protocols }\end{array}$ \\
\hline & $\begin{array}{l}\text { Keep } \\
\text { following } \\
\text { health } \\
\text { protocols }\end{array}$ & & \\
\hline
\end{tabular}

In terms of COVID-19 that causes grief for all of the sudden adaptation and significant health and economic loss, the Kübler-Ross cycle presents five stages of grief. It consists of denial, anger, bargaining, depression and acceptance [37]. The concept of Dua, Ikhtiar, Tawakkul and Tawadhu is expected to speed up or cut the step as it is said that each individual does not always experience the whole stages. This approach also builds up a belief that any stress is supposed to be eustress instead of distress. This belief is created by several key points, which includes: i) Dua, it creates a belief that there is a higher power that will help us, it makes us feel not alone and be able to overcome the situations; ii) Ikhtiar, by doing everything at best creates a positive value which also provide us with solution and solving the problem; iii) Tawakkul, after the best action comes to a perceive that the result will be in line with our action; and iv) Tawadhu, which makes us keep on track and not overconfidence of our deeds so we will continue to do dua, ikhtiar, and tawakkul.

\section{Conclusion}

The concept of Dua, Ikhtiar, Tawakkul, and Tawadhu during the COVID-19 pandemic is useful in coping with distress conditions. Spirituality and belief, as well as following health protocols appropriately, can suppress the body's response to stressors so that the body's immunity is maintained. It is expected that by implementing this concept, people will have a more resilient psychological state that provides a more robust immunity system.

Conflict of interest. The authors declare that there is no conflict of interest regarding the manuscript.

Author contribution. All authors are contributed equally to the content of the study.

\section{References}

1. Nations, U., Policy Brief: COVID-19 and the Need for Action on Mental Health. 2021, United Nations.

2. (WHO), W.H.O., Coronavirus Disease 2019 (COVID-19) Situation Report - 28. 2020, World Health Organization (WHO): Indonesia. p. 1-23.

3. Francisco $\mathrm{T}$ Ausk, I.E., Jan Moynihan, Psychoneuroimmunology. Dermatol Ther, 2008. 21 p. 22-31.

4. Brooks SK, W.R., Smith LE, Woodland L, Wessely $\mathrm{S}$, Greenberg N, et al., The psychological impact of quarantine and how to reduce it: rapid review of the evidence. Lancet, 2020. 395(10227): p. 912-20.

5. Neria Y, S.G., Understanding the mental health effects of indirectexposure to mass trauma through the media. JAMA, 2011. 306(12): p. 1374-5.

6. Nader Salari, A.H.-F., Rostam Jalali, Aliakbar VaisiRaygani, Shna Rasoulpoor, Masoud Mohammadi, Shabnam Rasoulpoor, Behnam Khaledi-Paveh, Prevalence of stress, anxiety, depression among the general population during the COVID-19 pandemic: a systematic review and meta-analysis. Globalization and Health, 2020. 16(57).

7. H, S., The Stress of Life. 1956, New York: McGrawHill.

8. Dhabhar FS, M.B., Acute stress enhances while chronic stress suppresses cell-mediated immunity in vivo: a potential role for leukocyte trafficking. Brain Behav Immun, 1997. 11(4): p. 286-306.

9. Brianna Chu, K.M., Terrence Sanvictores, Derek Ayers. Physiology, Stress Reaction. StatPearls 2021 2021 Sep 18 [cited 202101 August].

10. Ross, D., Distress vs. Eustress. Drake University. p. 1-3.

11. Victoria Branson, M.J.D., Edward Palmer, Deborah Turnbull, The Adolescent Distress-Eustress Scale:Development and Validation. SAGE Open, 2019. 9(3): p. 1-14.

12. Thaddeus W.W. Pace, L.T.N., Daniel D. Adame, Steven P. Cole, Teresa I. Sivilli, Timothy D. Brown, Michael J. Issa, Charles L. Raison, Effect of Compassion Meditation on Neuroendocrine, Innate Immune and Behavioral Responses to Psychosocial Stress. Psychoneuroendocrinology, 2009. 34(1): p. 87-98.

13. Dedy Syahrizal, R.F., Imam Maulana. Psychoneuroimmunology: The Approach for 
Increasing the Immunity of Disaster Victims. in 2017 Conference on Health Management in Post Disaster Recovery. 2017.

14. Gidron Y, R.K., Tissarchondou H, Warner J, The relation between psychological factors and DNAdamage: a critical review. Biol Psychol, 2006 72(3): p. 291-304.

15. Ballal K, W.C., Harmancey R, Taegtmeyer H, Obesogenic high fat western diet induces oxidative stress and apoptosis in rat heart. Mol Cell Biochem, 2010. 344(1-2): p. 221-30.

16. Yerkes RM, D.J., The relation of strength of stimulus to rapidity of habit-formation. J Comp Neurol Psychol, 1908. 18: p. 459-482.

17. Aschbacher K, O.D.A., Wolkowitz OM, Dhabhar FS, Su Y, Epel E Good stress, bad stress and oxidative stress: insights from anticipatory cortisol reactivity. Psychoneuroendocrinology 2013. 38(9): p. 1698-1708.

18. Aksa, F.I., Islamic perspectives in disaster: An alternative to changing fatalistic attitudes. Jàmbá: Journal of Disaster Risk Studies, 2020. 12(1): p. a942

19. Izet Pajević, O.S., Mevludin Hasanović, Association of Islamic Prayer with Psychological Stability in Bosnian War VeteransJournal of Religion and Health, 2017. 56(1): p. 2317-2329.

20. Azizunisak Hidayati Wahyuna, S.F., The Concept of Hope in The Western and Eastern Perspective. International Journal of Islamic Educational Psychology, 2020. 1(1): p. 1-12.

21. Librande, L., Studia Islamica. Vol. 100. 2005: Maisonneuve \& Larose.

22. Topbas, O.N. Tawadhu' (Humility). [cited 202120 June]; Available from: https://en.osmannuritopbas.com/tawadhuhumility.html.

23. Saniotis, A., Understanding Mind/Body Medicine from Muslim Religious Practices of Salat and Dhikr. J Relig Health, 2018. 57(3): p. 849-857.

24. Chittaranjan Andrade, R.R., Prayer and healing: $A$ medical and scientific perspective on randomized controlled trials. Indian J Psychiatry, 2009. 51(4): p. 247-253.

25. R Jevning, R.A., M Biedebach, G Fernando, Effects on regional cerebral blood flow of transcendental meditation. Physiol Behav, 1996. 59(3): p. 399-402.

26. Eileen Luders, K.C., Katherine L. Narr, Arthur W. Toga, Enhanced Brain Connectivity in Long-term Meditation Practitioners. Neuroimage, 2011. 57(4): p. 1308-1316.

27. Britta K. Hölzel, J.C., Mark Vangel, Christina Congleton, Sita M. Yerramsetti, Tim Gard, Sara W. Lazara, Mindfulness practice leads to increases in regional brain gray matter density. Psychiatry Res, 2011. 191(1): p. 36-43.

28. Amishi P. Jha, J.K., Michael J. Baime, Mindfulness training modifies subsystems of attention. Cognitive, Affective, \& Behavioral Neuroscience, 2007. 7: p. 109-119.

29. Britta K Hölzel, S.W.L., Tim Gard, Zev SchumanOlivier, David R Vago, Ulrich Ott, How Does
Mindfulness Meditation Work? Proposing

Mechanisms of Action From a Conceptual and Neural Perspective. Perspect Psychol Sci, 2011. 6(6): p. 537-59.

30. Peter Vestergaard-Poulsen, M.v.B., Joshua Skewes, Carsten R Bjarkam, Michael Stubberup, Jes Bertelsen, Andreas Roepstorff, Long-term meditation is associated with increased gray matter density in the brain stem. Neuroreport, 2009. 20(2): p. 170-4.

31. Yi-Yuan Tang, Q.L., Xiujuan Geng, Elliot A. Stein, Yihong Yang, Michael I. Posner, Short-term meditation induces white matter changes in the anterior cingulate. Proc Natl Acad Sci U S A, 2010. 107(35): p. 15649-15652.

32. J Kabat-Zinn, A.O.M., J Kristeller, L G Peterson, K E Fletcher, L Pbert, W R Lenderking, S F Santorelli, Effectiveness of a meditation-based stress reduction program in the treatment of anxiety disorders. Am J Psychiatry, 1992. 149(7): p. 936-43.

33. J J Miller, K.F., J Kabat-Zinn, Three-year follow-up and clinical implications of a mindfulness meditation-based stress reduction intervention in the treatment of anxiety disorders. Gen Hosp Psychiatry, 1995. 17(3): p. 192-200.

34. D Goldberg, A.H., A Furomoto-Dawson, H NelsonJohnson, Mindfulness-based stress reduction and its effects on well-being. Journal of Investigative Medicine, 1998. 46: p. 278A.

35. Grossman P, N.L., Schmidt S, Walach H, Mindfulness-based stress reduction and health benefits. A meta-analysis. J Psychosom Res, 2004. 57: p. 35-43.

36. N Deuraseh, M.A.T., Mental health in Islamic medical tradition. The International Medical Journal 2005. 4(2): p. 76-79.

37. Ann Scheck McAlearney, J.L.H., Cynthia J Sieck, Timothy R Huerta, The Journey through Grief: Insights from a Qualitative Study of Electronic Health Record Implementation. Health Serv Res, 2015. 50(2): p. 462-488. 